\title{
Donkey skin trade: is it sustainable to slaughter donkeys for their skin?
}

\section{Comércio de pele de jumentos: é sustentável abater jumentos para o uso de sua pele?}

\author{
Patricia Tatemoto $^{1}$ (D); Yuri Fernandes Lima ${ }^{2}$; Eduardo Santurtun ${ }^{2}$; Emily Reeves ${ }^{1}$; Zoe Raw ${ }^{1}$ \\ ${ }^{1}$ The Donkey Sanctuary, Sidmouth, Devon - United Kingdom \\ ${ }^{2}$ The Donkey Sanctuary, Mexico City - Mexico
}

\begin{abstract}
Donkeys (Equus asinus) face a global crisis. The health, welfare, and even survival of donkeys are being compromised as the demand for their skins increases. It is driven by the production of ejiao, a traditional Chinese remedy believed by some to have medicinal properties. It is estimated that the ejiao industry currently requires approximately 4.8 million donkey skins per year. Since there is no productive chain for donkey skin production outside of China, the activity is extractive and has resulted in the decimation of donkeys. Gestation is 12 months in donkeys, increasing the risk of extinction if such practices are not controlled. In this scenario, the donkeys are collected (purchased for low prices, stolen, and collected from the side of the roads) and are then often transported for long distances, usually without water, food, or rest. The trade, in Brazil, poses significant biosecurity risks, particularly because examinations are rarely conducted and therefore infectious diseases, such as glanders and infectious anemia, remain undetected. Furthermore, in chronic stress situations, the immune system is suppressed, increasing the biosecurity risk, especially because donkeys are a silent carrier of diseases. Rarely there is traceability with animals from different origins being put together in "fake farms", before being delivered to slaughterhouses. The opportunistic strategy of collecting animals, or buying for low prices, keeping them without access to food and veterinary assistance, is what makes this trade profitable. Our experience in donkey welfare and the global skin trade suggest that it will be enormously challenging and cost-prohibitive to run a trade at the standards required to be considered humane, sustainable, and safe. Although donkeys are being blamed for the involvement in road accidents, it is not an ethical solution to maintain this trade as an alternative. Moreover, the ecological role of donkeys in native ecosystems has not been elucidated, and some studies indicate they could even have a positive effect. Regardless of the future the donkeys will have; we must guarantee a life with the least dignity to the animals under our responsibility.
\end{abstract}

Keywords: Animal welfare. Sustainability. Biosecurity. Animal health. Donkey.

\section{RESUMO}

Os jumentos (Equus asinus) estão enfrentando uma crise global. A saúde, o bem-estar e até a sobrevivência dos jumentos estão sendo comprometidos à medida que a demanda por suas peles aumenta. A atividade é impulsionada pela produção de ejiao, um remédio tradicional chinês que algumas pessoas acreditam possuir propriedades medicinais. Estima-se que a indústria de ejiao demande atualmente cerca de 4,8 milhões de peles de jumento por ano. Uma vez que não existe uma cadeia produtiva fora da China, a atividade é extrativista e resultou na drástica redução das populações. A gestação dos jumentos é de 12 meses, aumentando o risco de extinção se tais práticas não forem controladas. Neste cenário, os jumentos são recolhidos (comprados a preços baixos, roubados e recolhidos à beira das estradas) e são frequentemente transportados para longas distâncias, normalmente sem água, comida ou descanso. O comércio no Brasil apresenta riscos significativos de biossegurança, principalmente porque os exames raramente são realizados e, portanto, doenças infecciosas, como mormo e anemia infecciosa equina, permanecem sem detecção. Além disso, em situações de estresse crônico, o sistema imunológico é suprimido, aumentando o risco de biossegurança, principalmente porque os jumentos são portadores silenciosos de doenças. Raramente há rastreabilidade, e os animais de diferentes origens acabam sendo colocados em "fazendas fantasma", antes de serem entregues aos abatedouros. A estratégia oportunista de coletar animais, ou comprar por preços irrisórios, mantendo-os sem acesso a alimentação e assistência veterinária, é o que torna esse comércio lucrativo. Nossa experiência em bem-estar de jumentos e no comércio global de peles sugere que 
será extremamente desafiador e com custo proibitivo administrar um comércio dentro dos padrões exigidos para ser considerado humano, sustentável e seguro. Embora os jumentos sejam responsabilizados pelo envolvimento em acidentes rodoviários, não é uma solução ética manter este comércio como uma alternativa. Além disso, o papel ecológico dos jumentos nos ecossistemas nativos não foi elucidado, e alguns estudos indicam que eles podem até ter um efeito positivo. Independentemente do futuro que os jumentos terão, devemos garantir uma vida com o mínimo de dignidade aos animais sob nossa responsabilidade.

Palavras-chave: Bem-estar animal. Sustentabilidade. Biossegurança. Saúde animal. Jumento.

Correspondence to:

Patricia Tatemoto

The Donkey Sanctuary

Slade House Farm, Sidmouth

Devon EX10 0NU, United Kingdom

e-mail: patricia.tatemoto@gmail.com

Received: August 28, 2020

Approved: December 22, 2020

How to cite: Tatemoto P, Lima YF, Santurtun E, Reeves E, Raw Z. Donkey skin trade: is it sustainable to slaughter donkeys for their skin? Braz J Vet Res Anim Sci. 2021;58(special issue):e174252. https://doi.org/10.11606/issn.1678-4456. bjvras.2021.174252

\section{Introduction}

The increasing demand for donkey skins is severely compromising the health, welfare, and even survival of donkeys. It is driven by the production of ejiao, a traditional Chinese remedy believed by some to have medicinal properties. Traditional Chinese medicine recommends the "ejiao" for blood circulation, anemia, insomnia, and vertigo (Shen et al., 2016). In Brazil, there are no donkey breeding farms to supply this demand. Animals are collected (in the case of abandonment), bought, and accumulated on "fake farms" until the numbers are sufficient to compensate for the transport to the slaughterhouse. The fake farms are not officially registered as producing donkeys, and receive, select, and maintain donkeys for days before sending them to the slaughterhouses (data collected in our fieldwork).

Throughout these steps, from collection to slaughter, donkeys are mistreated (The Donkey Sanctuary, 2019). They spend many hours confined during transport, and often do not have access to adequate water and food, or any veterinary care (evidence in the official complaints in the Public Ministry of Bahia state, Brazil). Animals are collected from various locations, which leads to long periods spent during transport. The lack of veterinary assistance leads to a lack of assistance, and then, negligence. The mistreatment of animals is a crime according to Brazilian legislation (Brasil, 1998). Not only it is important to give attention to donkey welfare (McLean \& Navas Gonzalez, 2018), but also the sustainability of the donkey skin trade (Carneiro et al., 2018).

Economically, this extractive relationship is unsustainable. This imbalance has conferred exploitation, including animal collection, transportation, land use, and labor. In this case, the economic externalities, such as animal mistreatment and prejudice of the Brazilian agribusiness image, are immeasurable. Since the biosecurity risks are evident, the agribusiness image of Brazil could be hugely compromised by the questionable traceability of animals within the industry. For instance, one positive case of glanders in horses in Germany led to the suspension of horse exports to Australia for six months (Warne, 2015).

Furthermore, at current rates of donkey slaughter, the prediction is that in four years the donkey will be extinct in Brazil (Conselho Regional de Medicina Veterinária do Estado da Bahia, 2018). In this scenario, it is unsustainable to send the donkeys to the slaughterhouse (Figure 1). Here, we describe the donkey welfare challenges, biosecurity risks, and risk of extinction involved in the donkey skin trade. Finally, we propose a sustainable future for the animal species that worked so hard building communities across the globe, including in Brazil.

\section{Donkey Welfare Challenges}

The welfare of an individual is defined as the state regarding its attempts to cope with the environment (Broom \& Johnson, 1993). Animal welfare guidelines are based on scientific knowledge. The recommendations about how to provide the management of any animal must be previously accepted by the scientific community. There is a dearth of information regarding the stunning and humane slaughter of donkeys. Even for reproduction, and farming, there are significant knowledge gaps. Without knowing what a species needs, it is not safe to provide recommendations. The five freedoms can provide a guide for general needs, but it is extremely important to develop scientific knowledge for 


\section{4,8 MILLION DONKEY SKINS ANNUALLY}
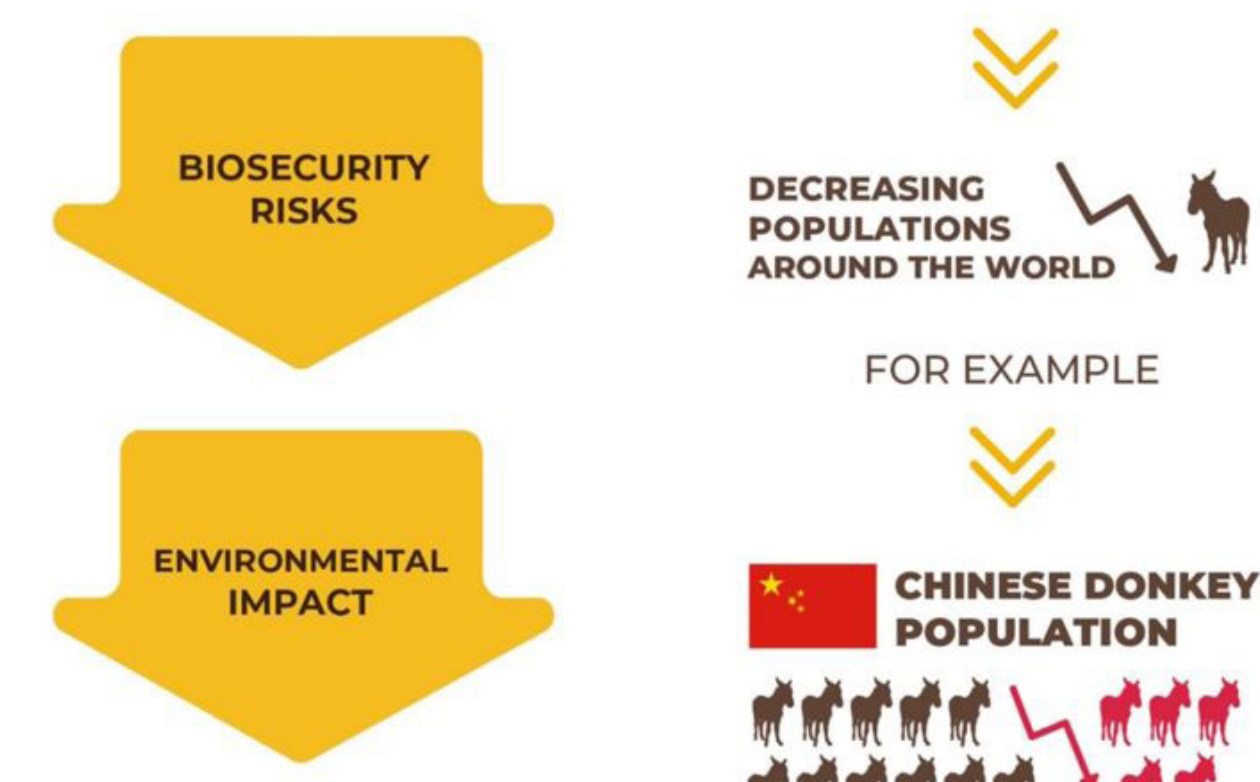

FOR EXAMPLE
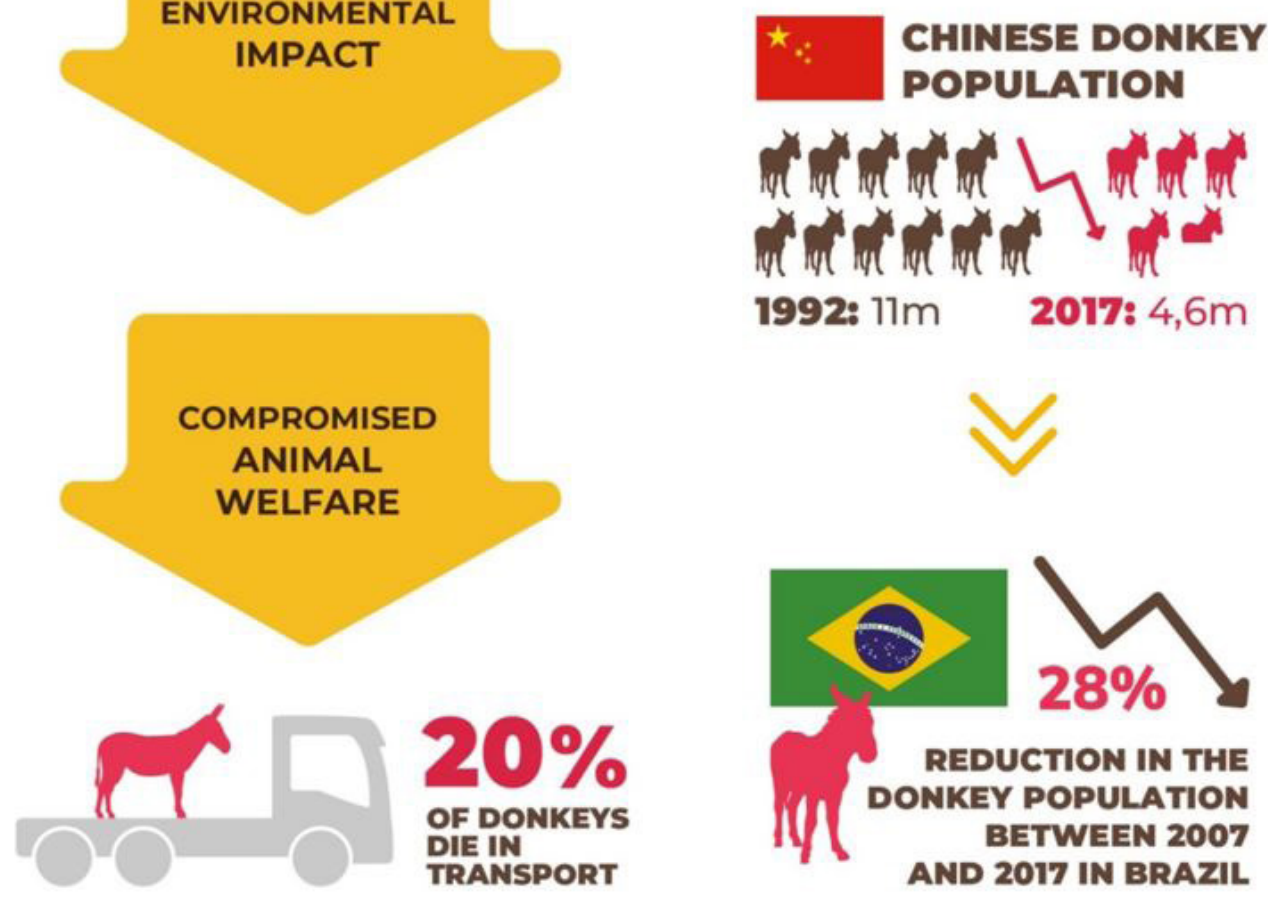

Figure 1 - Summary of the donkey skin trade demand and impact. The demand for donkey skins is estimated at 4.8 million annually, which is decreasing populations around the world.

constructing species-specific guidelines and to safeguard the right of any sentient individual to not suffer.

The donkey skin trade in the Northeast of Brazil starts with the collection of feral donkeys. Commonly, they are taken as roaming animals, bought for a low price, or even stolen. There are welfare problems associated with the capture of donkeys particularly since handlers have limited if any, experience in the handling of donkeys. Welfare challenges exist in the capture, loading, and transport of farmed animals even where years of scientific knowledge exist. For instance, there are still welfare problems related to capture, transport, and stunning farmed species such as cattle and pigs. Moreover, the specifications on stunning
(Berg \& Raj, 2015; Verhoeven et al., 2015), and the loss of consciousness (Terlouw et al., 2016) are species-specific. As such, it is necessary to have sound scientific evidence of the requirements for the humane slaughter of donkeys before it is permitted to continue across the globe.

Based on the information we collected in the field, stocking densities during transport are usually excessive and inappropriate for the species and there are some reports of long distances during which donkeys are not provided the opportunity to rest, drink or eat. In our fieldwork in Brazil, traders admitted that many donkeys arriving at "fake farms" are already dead (The Donkey Sanctuary, 2019). To fit any truck for the transport of living beings, it is mandatory to 
follow the recommendation of legislative instruments in Brazil, such as Resolution number 791, from June $18^{\text {th }}$, 2020, of the National Traffic Council. The trucks used to transport donkeys do not meet these requirements and, as such, the transportation of donkeys often compromises their welfare. For instance, this regulation mentions that the truck transporting donkeys must be adapted by species, and category of the transported animals, including specifications such as vehicle height, size, floor type, etc. The resolution also states that the truck must permit the ventilation of air; guarantee the welfare of animals; minimize extreme temperature effects; allow the partial visualization of the animals inside, and measures to provide water.

Since there is no livestock production for donkeys involved in the skin trade in Brazil, farms are not prepared or equipped for that purpose (see Figures 2 and 3). Despite this, in Brazil, there were complaints about donkeys being kept in the "fake farms", without provision for basic needs, such as water, food, and veterinary assistance (see Figures 2 and 3). Metabolic diseases such as hyperlipemia might be the cause of mortality of donkeys after being transported from different areas of the Northeast of Brazil.
Donkeys can have hyperlipemia, a disease caused by excess fat in the blood (The Donkey Sanctuary, 2018; Figure 4). In a situation in which a donkey, or any other animals susceptible to hyperlipemia, stops eating enough food, it starts a negative energy balance. The animal's essential organs still require a food supply, so the body tries to use energy that is stored as fat deposits. The outcome of this physiological process is that free fatty acids circulate to the liver, to be converted to glucose since it is a chemical form the body can use (Burden et al., 2011). All the steps in this physiological system are controlled by complex mechanisms, involving hormones. One of the negative feedbacks expected should be to shut down the amount of fat released from fat stores as the liver produces glucose for the body. However, animals susceptible to this syndrome do not have a physiological mechanism to efficiently turn off the fat release and the blood becomes saturated by fat in circulation (Bergero \& Nery, 2008; Mendoza et al., 2019). The etiology of this disease is known by stress that will cause a feed intake reduction, and stressors such as pain, transport, sudden dietary change, social mixing, sudden weight loss, and bad weather (Bergero \& Nery, 2008; Mendoza et al.,
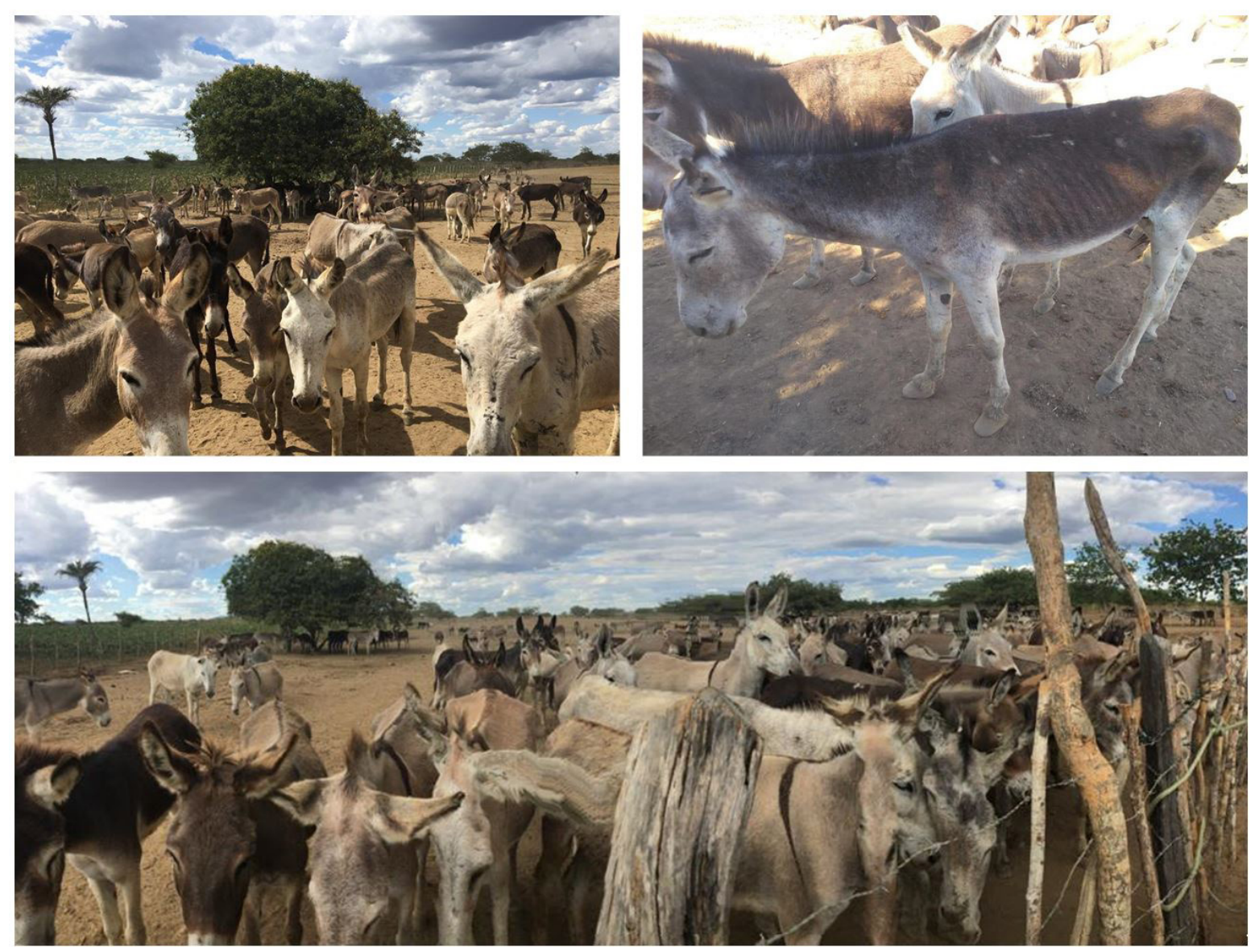

Figure 2 - Body condition scoring of apprehended donkeys. Most individuals had a poor body condition scoring (The Donkey Sanctuary, 2013) in the fake farm (Santa Isabel Farm, Canudos city, Bahia state, Brazil), without provision for basic needs, such as water, food, and veterinary assistance. 

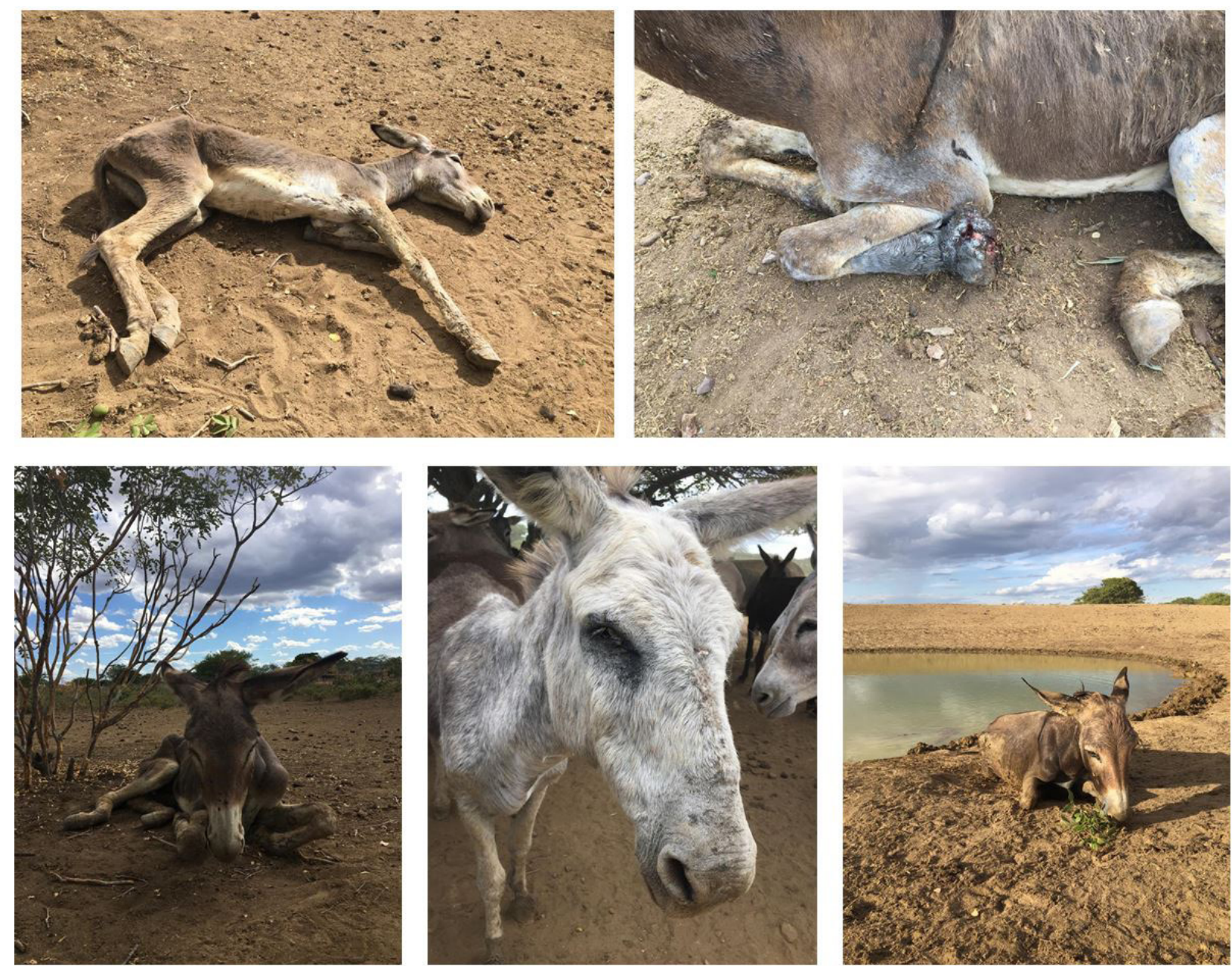

Figure 3 - Animals showing indicators of impaired welfare, in which they needed veterinary care. Despite the body condition scoring, some animals showed ocular secretion, parasites, skin wounds, and problems in the hoof integrity. Moreover, many animals were prostrated, and unable to stand. The veterinarians suspected that it was hyperlipemia, due to the history of stress and poor nutrition.

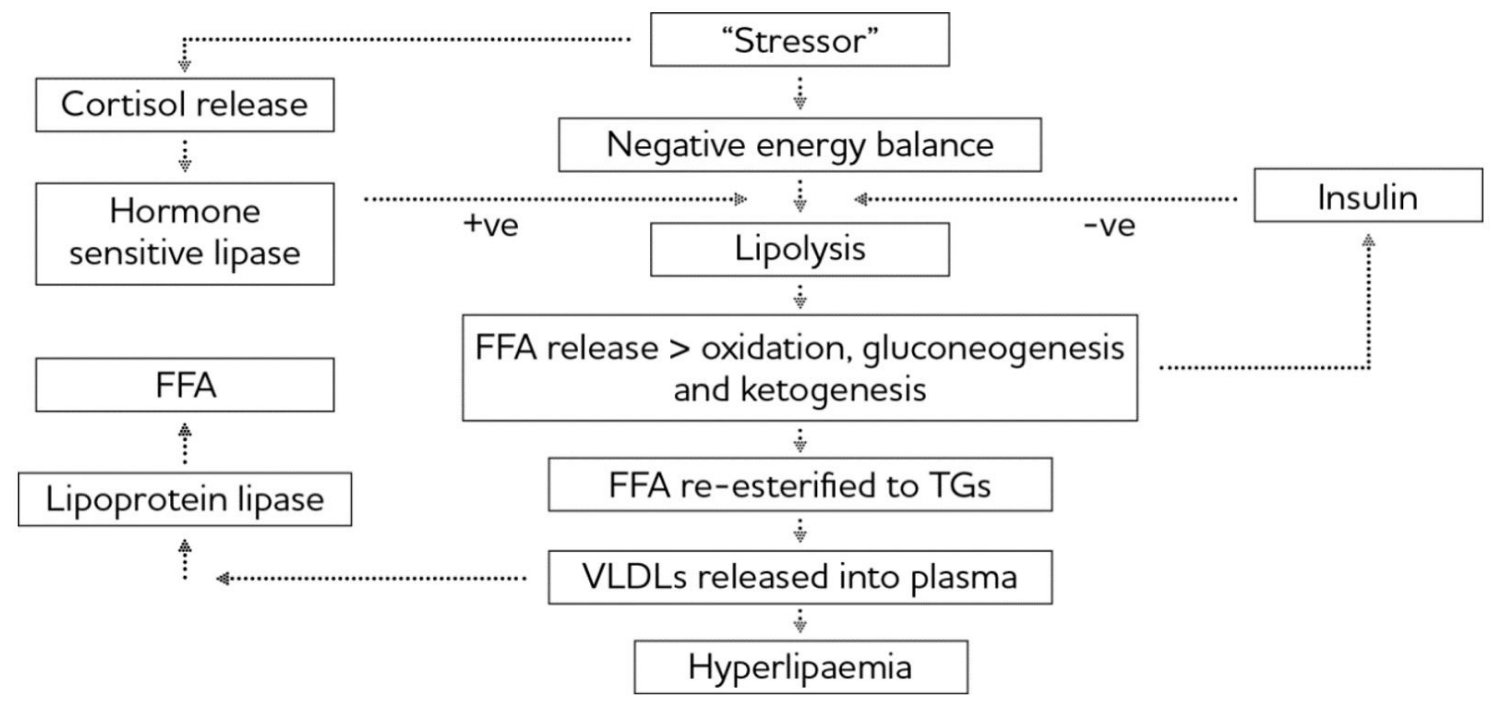

Figure 4 - Hyperlipemia physiological cascade (Reproduced from The Donkey Sanctuary, 2018).

2019). Based on this, we suspect that hyperlipemia was the reason why the donkeys were prostrated and dying in high frequency (sometimes 12 donkeys in one day, in the farm based in Canudos city, a case we closely followed).
Donkeys delivered to slaughterhouses are transported under the same inhumane conditions seen in transport to the "fake farms." As there is no scientific knowledge nor guidelines specific to donkeys, likely, slaughterhouse workers 
are not applying the necessary tools to implement a humane slaughter. The contention boxes used to immobilize the animal, and to ensure humane stunning (see review Verhoeven et al., 2015), is adapted from contention boxes designed for other farm animals. Moreover, the stunning must make a loss of consciousness immediately (Verhoeven et al., 2015), and since there is no available scientific knowledge for donkeys and training for the operators, the quality control of those procedures is questionable. It is not possible to adapt the available scientific knowledge from horses to donkeys as they are different species with unique characteristics, such as pain behavior (Regan et al., 2016). Also, we can mention the "Manual of Good Management Practices in Equideoculture," drafted by the Ministry of Agriculture of Brazil, that is specific to horses and mentions that

The references presented for horses in this manual can be applied to other equines like donkeys, mules, and ponies. However, we recommend that doubts about exclusive care directed to these animals (equines not horses) must be resolved with the help of graduated specialists (Brasil, 2017, p.5).

\section{Biosecurity Risks}

The way the animals are collected from roads, without traceability, creates a huge biosecurity risk. The collected donkeys are subjected to acute stress, being captured and then transported in inhumane conditions to "fake farms." It is widely known that chronic stress is an immunosuppressant, and this is further compounded by inadequate access to food and water, making donkeys particularly vulnerable and likely to be a significant vector of diseases. Also, in the fake farms in Brazil, where donkeys are often held before being sent to the slaughterhouse, donkeys from different states were mixed, increasing the biosecurity risks (The Donkey Sanctuary, 2019). This not only compromises the health of equids but puts human health at risk.

In May 2019, in one fake farm in Canudos city, Bahia state, the Agricultural Defense Agency of Bahia registered 8 positive cases for glanders and 5 positives for equine infectious anemia (Agência Estadual de Defesa Agropecuária da Bahia, 2019), both infectious diseases requiring mandatory registration for equines in Brazil. In this scenario, public health is potentially compromised, since some of the diseases are zoonotic, such as glanders (Van Zandt et al., 2013). Glanders is an infectious disease, with a high potential of contagion, and is often fatal for horses, mules, and donkeys. Donkeys are more susceptible to develop acute types of glanders, while horses are more prone to develop a chronic form (Van Zandt et al., 2013).
Glanders has a lethality zoonosis up to $95 \%$ for humans (Van Zandt et al., 2013).

Moreover, there is a general risk of moving animals without traceability. There are other examples of diseases that have emerged from animals transported and held with insufficient biosecurity measures, such as pasteurellosis in cattle, salmonellosis in sheep (Adams, 1994), or zoonotic diseases like the Nipah virus outbreak in Malaysia (Uppal, 2000).

\section{Risk of Local Extinction}

At the current rate, the slaughters of donkeys will extinguish the species in Brazil, therefore violating the Federal Constitution (Brasil, 1988). The decline of populations across the globe has been reported (The Donkey Sanctuary, 2019) because of the global skin trade. The Donkey Sanctuary, researchers and scientists in veterinary science and animal science, estimate that in four years the donkey breed from Northeast region will disappear in Brazil. For the donkey skin trade, there are no donkey farms, but, on the contrary, the animals are accumulated in fake farms until the numbers are sufficient to compensate for their delivery to the slaughterhouse. The commercialization and slaughter of donkeys are unsustainable and puts national herds at risk (The Donkey Sanctuary, 2019).

Evidence demonstrates it could take at least 20 to 25 years to reach the number of skins, and then donkeys, required by the ejiao industry (Bennett \& Pfuderer, 2020). Data shows that donkey farming does not represent a quick return on investment, so it is not considered a solution to an increasingly unviable supply chain (The Donkey Sanctuary, 2019). Although good welfare practices could be introduced into donkey farming, the species has complex needs and lengthy reproduction cycles. The gestation period of a donkey is around 12 months. In a model developed by the University of Reading, considering a system in which a foal born from a breeding female every 17 months and only one percent mortality, a farming process with an initial herd of 200,000 female donkeys would take 15 years to supply 1.2 million skins (Bennett \& Pfuderer, 2020). This estimate assumes ideal conditions, which are unlikely to occur, and represents only one-quarter of the 4.8 million skins needed annually to sustain the industry (Bennett \& Pfuderer, 2020). This evidence shows that many years are necessary to build farms able to meet the demand and that promises of a quick return are not feasible (The Donkey Sanctuary, 2019).

The donkey population in Brazil is decreasing. The Brazilian Institute of Geography and Statistics (IBGE) 
reported a population of 974,688 donkeys in 2011 (Instituto Brasileiro de Geografia e Estatística, 2011). In 2017, the numbers dropped to 376,874 (Instituto Brasileiro de Geografia e Estatística, 2017), evidencing a decline of $38 \%$ in six years. According to the data of the Food and Agriculture Organization of the United Nations (2017), from 2008 to 2018, the reduction was $28 \%$ in Brazil. Although the decrease is different between the two official sources, the reduction of the donkey population in Brazil is clear.

The three slaughterhouses based in Bahia state were preparing to reach the capacity to slaughter 200,000 donkeys per year (Suarez, 2019). For instance, the slaughterhouse based in Amargosa city alone, slaughtered 44,000 donkeys from August 2017 to September 2018 (Brasil, 2018). Based on this, the prediction of donkey extinction in Brazil was optimistically four years. However, in 2018, the federal justice in Salvador city, Bahia state, granted an injunction prohibiting the slaughter of donkeys, and although this injunction was suspended one year later, to our knowledge, the three slaughterhouses are not culling as before the injunction. Since the data is not precise, it is a challenge to understand the scenario. Also, in this estimate, we are not considering the huge losses, deaths, and animals dying from diseases.

\section{Sustainable Future for the Donkeys}

\section{Road accidents}

In many countries, including Brazil, donkeys have been replaced by motorcycles and other forms of mechanization. No longer required, donkeys are abandoned by their owners and left to survive on their own. This was one of the main reasons why in some countries, such as Brazil, donkeys started to be abandoned. Without a role, they became street animals. As a result, donkeys started to invade roads and cause traffic accidents. In this scenario, donkey slaughter was presented as a possible solution for the problem attributed to the donkeys.

However, in Brazil, an estimated 475 million wild animals are involved in traffic accidents every year (Kafruni \& Souza, 2020; Universidade Federal de Lavras, 2020) Killing all these animals is neither a feasible nor ethical solution. It is necessary to discuss and implement public policies, in which the first step is to understand the problem for further developing a contingency plan. Around the world, studies have been developed for avoiding animals crossing the roads (Karaźniewicz et al., 2018; Malo et al., 2004; Thurfjell et al., 2015). The alternatives will depend on the biology of the species and the geographic region. For instance, bridges, tunnels, and corridors are some of the alternatives.

\section{Ecological role}

Donkeys have been introduced around the world to be used as working animals. They have also become part of the culture in many regions. Their utility as working animals made the species spread across different regions. The replacement of donkeys with mechanical technologies meant donkeys became surplus to need and a target for control of invasive species. However, it is again necessary to understand the ecological role in the ecosystem, which will vary by region and biome. Few studies are being conducted to elucidate this issue (Dias et al., 2019; Hamrick et al., 2005; Lamoot et al., 2005; Malo et al., 2016).

For instance, in Brazil donkeys are predominantly in the Northeast region. One of the biomes is the Caatinga, the only biome exclusively Brazilian. In this biome, the use of habitat by donkeys is unclear (Dias et al., 2019). One study investigated the use of habitats by donkeys in a protected area of the Caatinga dry forest (Dias et al., 2019). However, one of the variables interfering in the conclusion about the ecological role of donkeys is the combination with other species, including cattle (Dias et al., 2019). In the Caatinga dry forest biome, the only large herbivore is a deer (Mazama gouazoubira), but it is much smaller than a donkey and not so general in feeding behavior (Kufner et al., 2008; Prado, 2013). For example, native deer Mazama gouazoubira and the exotic hare Lepus europaeus were studied to assess the risk of competition for food. The differences in habitats, regarding feeding and use, allow both herbivores to coexist. However, competition for food probably exists during some seasons, such as the dry period, or because of anthropic actions, like habit loss (Kufner et al., 2008).

The thought that nature is in a balance is only partially correct since the interactions between living beings, populations, and species are complex and dynamic. Moreover, the ethical concern related to population control raised new discussions regarding the ecological role of each species, such as nativism (Wallach et al., 2018). The term was used in anthropology as a political policy protecting the interests of the native population and applying measures against immigrants. Nativism attributes intrinsic value to perceived native elements, identifying native species as a worthy target of moral concern (Wallach et al., 2018). However, nativism also imposes clear exclusions. This concept has been strongly guiding conservation research and policy. Nevertheless, since nativism is based on assumptions of ecosystems in static equilibrium, it is questionable since the ecosystems have dynamic and complex interactions. In this sense, some scientists are discussing inclusive conservation, which can change our view about the living world (Wallach et al., 2018). Although donkeys were introduced in many parts of 
the world, the ecosystems' equilibrium is dynamic, instead of static. In a globalization context, we must start to accept our introduction of some species and try to mitigate the consequences.

The ecological role and the potential impact of donkeys in native ecosystems are still inconclusive (Dias et al., 2019; Hamrick et al., 2005; Lamoot et al., 2005; Malo et al., 2016). Some variables are affecting the conclusions, and the discussions must consider other species, population size, territory, vegetation, etc. Moreover, the species control is worthy of moral concern, in which it is not acceptable to compromise the welfare of any species, because in the past humans included and, in the case of donkeys, abandoned the animals that started to survive in new ecosystems. A full environmental assessment is required before proceeding with the slaughter of donkeys as an ecological solution.

Additionally, exotic species have been displaced and inserted into native forest areas. Some of these species, over the years, have occupied new ecological niches and played important roles in ecosystems. Studies are needed to understand the interspecific relations of the donkey in Caatinga, which is a unique biome in the world.

\section{Cellular agriculture}

There is an increasing number of alternatives to animal products, based on an ethical trend to avoid animal suffering and exploitation. Besides, the demand for sustainable products considering the environmental impact has also fostered the need for alternative productions. Great strides have been taken in the field of biotechnology. Cellular agriculture seems a feasible and promising option in this context and has been discussed for providing all humans with quality food that meets basic nutritional requirements, consumer desire, and sustainable land use (Arora et al., 2020; Reis et al., 2020).

For this new trend to work, it is necessary to engage stakeholders, such as policymakers, entrepreneurs, and others, to design a strategy about how to advance an agenda for investments (Reis et al., 2020). It is also necessary to provide funding to build knowledge, to make it more feasible, cheap, and safe. In this scenario, universities and scientists are extremely important.

Cellular agriculture has the potential to meet the demands of consumers concerned with animal welfare and ethics in farming production. Moreover, this would meet the concerns of people engaged with environmental impact and climate changes.

\section{Conclusion}

If it continues at the current rate, the skin trade will extinguish local populations of donkeys. In Brazil, there are no donkey production farms, once the animals are collected, or bought, and sent to slaughterhouses. The commercialization and slaughter of donkeys are unsustainable and have led to decimated local populations in other countries. Furthermore, the extractive strategy of this trade causes enormous damage to our resources, which includes the extinction of the species, animal welfare, environmental impact, biosecurity and public human health risks, and noncompliance with Brazilian law. Also, the potential negative impact on Brazil's image as a leader in agribusiness is immeasurable. These animals, sentient and hardworking beings, experience indescribable suffering in the name of the global skin trade. The donkey skin trade is unsustainable and must be stopped until it is proven to be sustainable, humane, and safe.

\section{Conflict of Interest}

The authors declare there is no conflict of interest.

\section{Acknowledgements}

We would like to acknowledge and recognize, the participation of all stakeholders in Brazil, including the National Front for the Defense of Donkeys, University of São Paulo, Federal University of Bahia, Professor Pierre Escodro, Professor Chiara Albano, and Professor Adroaldo José Zanella.

\section{References}

Agência Estadual de Defesa Agropecuária da Bahia - ADAB. Nota técnica - ADAB mantém medidas preventivas em relação aos asininos [Internet]. Salvador: ADAB; 2019. Available from: http://www.adab.ba.gov.br/2019/05/1911/Nota-tecnica-ADAB-mantem-medidas-preventivas-emrelacao-aos-asininos.html
Adams DB. Transportation of animals and welfare. Rev Sci Tech. 1994;13(1):153-69. PMid:8173094.

Arora RS, Brent DA, Jaenicke EC. Is India ready for alt-meat? Preferences and willingness to pay for meat alternatives. Sustain. 2020;12(11):4377. http://dx.doi.org/10.3390/su12114377. 
Bennett R, Pfuderer S. The potential for new donkey farming systems to supply the growing demand for hides. Animals. 2020;10(4):718. http://dx.doi.org/10.3390/ani10040718. PMid:32326062.

Berg C, Raj M. A review of different stunning methods for Poultry: animal welfare aspects (stunning methods for poultry). Anim. 2015;5(4):1207-19. http://dx.doi.org/10.3390/ ani5040407. PMid:26633521.

Bergero D, Nery J. Hepatic diseases in horses. J Anim Physiol Anim Nutr. 2008;92(3):345-55.http://dx.doi.org/10.1111/j.14390396.2007.00798.x. PMid:18477316.

Brasil. Constituição da República Federativa do Brasil. Diário Oficial da União [Internet]. Brasília; 1988 Oct 5. Available from: http://www.planalto.gov.br/ccivil_03/constituicao/ constituicao.htm

Brasil. Lei no 9.605 , de 12 de fevereiro de 1998. Dispõe sobre as sanções penais e administrativas derivadas de condutas e atividades lesivas ao meio ambiente, e dá outras providências. Diário Oficial da União [Internet]. Brasília; 1998 Feb. 12. Available from: http://www.planalto.gov.br/ccivil_03/leis/ 19605.htm

Brasil. Ministério da Agricultura, Pecuária e Abastecimento. Indicadores gerais Agrostat [Internet]. Brasília; 2018. Available from: http://indicadores.agricultura.gov.br/agrostat/index.htm

Brasil. Ministério da Agricultura, Pecuária e Abastecimento. Secretaria de Mobilidade Social, do Produtor Rural e Cooperativismo. Manual de boas práticas de manejo em equideocultura. Brasília: MAPA/ACE/CGCS; 2017.

Broom DM, Johnson KG. Approaching questions of stress and welfare. In: Broom DM, Johnson KG, editors. Stress and animal welfare. Dordrecht: Springer; 1993. p. 1-7.http://dx.doi. org/10.1007/978-94-024-0980-2_1.

Burden FA, Du Toit N, Hazell-SmithE, Trawford AF. Hyperlipemia in a population of aged donkeys: description, prevalence, and potential risk factors. J Vet Intern Med. 2011;25(6):1420-5.. http:// dx.doi.org/10.1111/j.1939-1676.2011.00798.x. PMid:22092637.

Carneiro GF, Lucena JEC, Barros LO. The current situation and trend of the donkey industry in South America. J Equine Vet Sci. 2018;65:106-10. http://dx.doi.org/10.1016/j.jevs.2018.03.007.

Conselho Regional de Medicina Veterinária do Estado da Bahia. Solicitação de suspensão das atividades de abate de asininos no Brasil, dirigida à Comissão Nacional de Bem-
Estar Animal do Conselho Federal de Medicina Veterinária - COBEA/CFMV. Salvador; 2018.

Dias DM, Massara RL, Bocchiglieri A. Use of habitats by donkeys and cattle within a protected area of the Caatinga dry forest biome in northeastern Brazil. Perspect Ecol Conserv. 2019;17(2):64-70.http://dx.doi.org/10.1016/j.pecon.2019.04.005.

Food and Agriculture Organization of the United Nation. FAOSTAT [Internet]. Rome: FAO; 2017 [cited 2007 Aug 28]. Available from: http://www.fao.org/faostat/en/\#data/EMN

Hamrick RG, Pirgalioglu T, Gunduz S, Carroll JP. Feral donkey Equus asinus populations on the Karpaz peninsula, Cyprus. Eur J Wildl Res. 2005;51(2):108-16. http://dx.doi.org/10.1007/ s10344-005-0085-0.

Instituto Brasileiro de Geografia e Estatística - IBGE. Censo agropecuário [Internet]. 2011 [cited 2007 Aug 28]. Available from: ftp://ftp.ibge.gov.br/Producao_Pecuaria/Producao_da_ Pecuaria_Municipal/2012/tabelas_pdf/tab13.pdf

Instituto Brasileiro de Geografia e Estatística - IBGE. Censo agropecuário [Internet]. 2017 [cited 2007 Aug 28]. Available from: https://censos.ibge.gov.br/agro/2017/templates/censo_agro/ resultadosagro/pecuaria.html? localidade $=0 \&$ tema $=75642$

Kafruni S, Souza R. Travessia dos inocentes [Internet]. 2020 [cited 2020 Aug 17]. Available from: https://www.correiobraziliense. com.br/brasil/2020/08/4867269-travessia-dos-inocentes.html

Karaźniewicz J, Sołtyszewski I, Malewski T, Szarek J, Felsmann M, Grudzień W, Dzikowski A. Review of procedures concerning animals involved in traffic accidents - Including own investigations. Pol J Nat Sci. 2018;33(3):503-16.

Kufner MB, Sepúlveda L, Gavier G, Madoery L, Giraudo L. Is the native deer Mazama gouazoubira threatened by competition for food with the exotic hare Lepus europaeus in the degraded Chaco in Córdoba, Argentina? J Arid Environ. 2008;72(12):2159-67. http://dx.doi.org/10.1016/j. jaridenv.2008.07.005.

Lamoot I, Callebaut J, Demeulenaere E, Vandenberghe C, Hoffmann M. Foraging behaviour of donkeys grazing in a coastal dune area in temperate climate conditions. Appl Anim Behav Sci. 2005;92(1-2):93-112. http://dx.doi.org/10.1016/j. applanim.2004.10.017.

MaloJE, González BA, Mata C, Vielma A, Donoso DS, Fuentes $\mathrm{N}$, Estades CF. Low habitat overlap at landscape scale between 
wild camelids and feral donkeys in the Chilean desert. Acta Oecol. 2016;70:1-9. http://dx.doi.org/10.1016/j.actao.2015.11.002.

Malo JE, Suárez F, Díez A. Can we mitigate animal-vehicle accidents using predictive models? J Appl Ecol. 2004;41(4):70110. http://dx.doi.org/10.1111/j.0021-8901.2004.00929.x.

McLean AK, Navas Gonzalez FJ. Can scientists influence donkey welfare? Historical perspective and a contemporary view. J Equine Vet Sci. 2018;65:25-32. http://dx.doi.org/10.1016/j. jevs.2018.03.008.

Mendoza FJ, Toribio RE, Perez-Ecija A. Metabolic and endocrine disorders in donkeys. Vet Clin North Am Equine Pract. 2019;35(3):399-417. http://dx.doi.org/10.1016/j. cveq.2019.07.001. PMid:31587976.

Prado HM. Feeding ecology of five Neotropical ungulates: a critical review. Oecol Aust. 2013;17(4):459-73. http://dx.doi. org/10.4257/oeco.2013.1704.02.

Regan FH, Hockenhull J, Pritchard JC, Waterman-Pearson AE, Whay HR. Identifying behavioral differences in working donkeys in response to analgesic administration. Equine Vet J. 2016;48(1):33-8. http://dx.doi.org/10.1111/evj.12356. PMid:25256702.

Reis GG, Heidemann MS, Borini FM, Molento CFM. Livestock value chain in transition: cultivated (cell-based) meat and the need for breakthrough capabilities. Technol Soc. 2020;62:101286. http://dx.doi.org/10.1016/j.techsoc.2020.101286.

Shen L, Chen H, Zhu Q, Wang Y, Wang S, Qian J, Wang Y, $\mathrm{Qu} \mathrm{H}$. Identification of bioactive ingredients with immunoenhancement and anti-oxidative effects from Fufang-Ejiao-Syrup by LC-MSn combined with bioassays. J Pharm Biomed Anal. 2016;117:363-71. http://dx.doi.org/10.1016/j.jpba.2015.09.024. PMid:26433168.

Suarez J. A demanda chinesa que ameaça o jumento brasileiro: Como um acordo com a China provocou uma corrida ao abate de asininos e agora ameaça a espécie símbolo do Nordeste. El País [Internet]; 2019 Dec 11. Available from: https://brasil. elpais.com/brasil/2019-12-11/sob-a-pele-do-jumento.html

Terlouw C, Bourguet C, Deiss V. Consciousness, unconsciousness and death in the context of slaughter. Part II. evaluation methods. MeatSci. 2016;118:147-56. http://dx.doi.org/10.1016/j. meatsci.2016.03.010. PMid:27086068.
The Donkey Sanctuary. Factsheet: owners [Internet]. United Kingdom; 2013. Available from: https://www.thedonkeysanctuary. org.uk/sites/uk/files/2018-12/condition-scoring-and-weightestimation-of-the-donkey-20181211.pdf

The Donkey Sanctuary. The clinical companion of the Donkey. 1st ed. United Kingdom: Troubador Publishing; 2018.

The Donkey Sanctuary. Under the skin: update on the global crisis for donkeys and the people who depend on them [Internet]. United Kingdom; 2019 Available from: https:// www.thedonkeysanctuary.org.uk/sites/uk/files/2019-12/ under-the-skin-report-english-revised-2019.pdf

Thurfjell H, Spong G, Olsson M, Ericsson G. Avoidance of high traffic levels results in lower risk of wild boar-vehicle accidents. Landsc Urban Plan. 2015;133:98-104. http://dx.doi. org/10.1016/j.landurbplan.2014.09.015.

Universidade Federal de Lavras - UFLA. CBEE: Centro Brasileiro de Estudos em Ecologia de Estradas [Internet]. 2020. Available from: http://cbee.ufla.br/portal/atropelometro/

Uppal PK. Emergence of Nipah virus in Malaysia. Ann NY Acad Sci. 2000;916(1):354-7.http://dx.doi.org/10.1111/j.1749-6632.2000. tb05312.x. PMid:11193645.

Van Zandt KE, Greer MT, Gelhaus HC. Glanders: an overview of infection in humans. Orphanet J Rare Dis. 2013;8(1):131. http://dx.doi.org/10.1186/1750-1172-8-131.PMid:24004906.

Verhoeven MTW, Gerritzen MA, Hellebrekers LJ, Kemp B. Indicators used in livestock to assess unconsciousness after stunning: a review. Animal. 2015;9(2):320-30. http://dx.doi. org/10.1017/S1751731114002596. PMid:25354537.

Wallach AD, Lundgren EJ, Ripple WJ, Ramp D. Invisible megafauna. Conserv Biol. 2018;32(4):962-5. http://dx.doi. org/10.1111/cobi.13116. PMid:29693743.

Warne S. How glanders in Germany has affected global equine transportation. Eurodressage; $2015 \mathrm{Feb} 28$. Available from: https://eurodressage.com/2015/02/28/how-glandersgermany-has-affected-global-equine-transportation-0

Financial Support: None. 